\title{
Developments in the Law of Confidentiality
}

\author{
The Hon. Mr Fustice Scott
}

The law of confidentiality is a creature with many heads. It is capable of covering the secrets of the marriage bed,' the confidential details of a manufacturing process, ${ }^{2}$ the secrets of $\mathrm{MI} 5,{ }^{3}$ privileged documents disclosed by mistake, ${ }^{4}$ information about clients' affairs obtained by a financial services company, ${ }^{5}$ or about a patient obtained by his doctor, ${ }^{6}$ information obtained from telephone tapping ${ }^{7}$ or from commercial espionage. In each of the situations described, as well as in a variety of others, the person in whom the information reposes may find himself (or herself) subjected to an injunction not to disclose or not to make use of the information or liable in damages (or for an account of profits) for the use already made of the information.

There is no one clear source of the legal obligations imposed by the law for the protection of confidential information. In some contexts the law of contract is the obvious source. This will be so where the relationship between the person to whom the duty is owed and the person on whom the duty is laid is or has been a contractual one. In the Spycatcher case Mr Peter Wright had been an officer of MI5 and in that capacity had acquired the knowledge of MI5 affairs that he purported to reveal in his book. Obligations of confidence and secrecy were imposed on him by the nature of his employment in MI5. There is a plethora of cases in which obligations of confidence in relation to commercial information have been held to be owed by employees to their employers. ${ }^{8}$ These obligations are generally treated as arising under implied terms in the contracts of employment. But there are many cases outside the field of contract in which similar obligations have been imposed for the protection of confidential information. In some, analogies with rights of property have been drawn in order to explain the

1. Argyll v. Argyll [1967] Ch. 302.

2. Seager v. Copydex [1967] 1 W.L.R. 23.

3. Attorney General v. Guardian Newspapers Ltd. (No 2) [1988] 3 W.L.R. 776.

4. Ashburton v. Pape [1913] 2 Ch. 469.

5. Re a Company [1989] Ch. 477.

6. W. v. Egdell [1989] 2 W.L.R. 689.

7. Francome v. Mirror Group Newspapers [1984] I W.L.R. 892.

8. See, e.g., Cranleigh Precision Engineering Ltd. v. Bryant [1965] I W.L.R. 1293; Coco v. A. N. Clark (Engineers) Ltd. [1969] R.P.C. 41. 
protection being afforded to the confidential information. ${ }^{9}$ In others, general principles of equity, of "obligations of conscience", have been used to justify the protection of the confidential information. In Seager v. Copydex, ${ }^{10}$ Lord Denning MR said:"11

"It depends upon the broad principle of equity that he who receives information in confidence shall not take unfair advantage of it."

And Swinfen Eady J in Ashburton v. Pape ${ }^{12}$ said: ${ }^{13}$

"The principle upon which the Court of Chancery has acted for many years has been to restrain the publication of . . . information imparted in confidence which ought not be divulged."

In the family cases, such as Argyll v. Argylli4 and Stephens v. Avery, ${ }^{15}$ the protection afforded to the respective plaintiffs can hardly be attributed to any contractual or proprietory source and can only be attributed to the application of a general principle of law.

In many cases, analysis of the relevant facts enables the protection of the information in question to be justified on more than one of the possible bases I have mentioned. In the employment cases, both commercial and governmental, implied contract and equity may seem to cover the same ground. In the case which is the granddaddy of them all, Prince Albert v. Strange, ${ }^{16}$ the injunction granted to restrain the exhibition of the Prince Consort's etchings was based on breach of trust, breach of contract, property rights in the etchings, as well as on breach of confidence. And if, in a particular case, it seems obvious that an injunction should be granted, it may be thought pedantic to insist on a rigorous analysis of the true basis on which the relief can be justified.

But an exclusively pragmatic approach may lead to difficulties. Unless, in confidential information cases, it is made clear what principle of law is being applied the application of the law to new factual situations, which are bound from time to time to arise, will be haphazard. And, worse, if the wrong principle of law is applied, the result of the case may be injustice and the law may be driven down a $c u l-d e-s a c$ from which there is no escape bar legislation.

My purpose in this article is to examine two particular types of case, to both of which principles of the law of confidentiality have been applied. My preceding

9. See, e.g., Exchange Telegraph v. Gregory [1896] I Q.B. 147 and re Keane [1922] Ch. 475.

10. [1967] I W.L.R. 923.

11. At p.931.

12. [1913] 2 Ch. 469.

13. At page 475 .

14. [1967] Ch. 302.

15. [1988] Ch. 449.

16. (1849) I Mac. \& G. 25. 
remarks are intended as a preface to that examination. One type of case concerns the extent of the duty owed by an ex-employee to his or her previous employer not to disclose or make use of the employer's confidential commercial information. The other type of case concerns the extent to which a duty not to mis-use confidential information can be used to provide some protection against the invasion of privacy. I will start with the former.

\section{The duty of confidence owed by an ex-employee to an ex-employer}

It is, I think, obvious that the source of whatever duties of confidence are owed by an employee to his or her employer, whether during or after the termination of the contract of employment, must be the contract itself. The contract may contain an express term dealing with the matter. If it does then, unless the term is unenforceable on restraint of trade or other public policy grounds, the extent of the duties it imposes will be a matter of construction of the contractual term. If, however, there is no express term then, if a duty is to be imposed on the employee, it must be justified by reference to an implied term. The terms that can be implied into a particular contract will generally depend upon the circumstances of the particular case. All lawyers will be familiar with the well known and much used " "officious bystander" " and " "necessary to give efficacy to the contract" "criteria. There are in addition terms that will be implied into a contract as a matter almost of legal presumption. ${ }^{17}$ Of this latter sort is, probably, the so-called "duty of fidelity" that the law generally regards as owing by any employee to his or her employer. ${ }^{18}$ The duty of an employee not to disclose his employer's confidential information is, at least while the employment continues, probably best regarded as one aspect of the implied duty of fidelity. But what of the position after the employment has come to an end? It is not arguable, and has not as far as I know been argued, that the implied duty of fidelity can survive the termination of the employment. So on what basis can a continued duty of confidence be regarded as owing by the ex-employee? Why should an ex-employee not be entitled to use for his own purposes, including that of competition with his ex-employer, all and any information that he has acquired in the course of his employment? The answer to these questions must, in my opinion, be found by an application of the principles of the law of contract. In every case the question that must be asked is whether a term can be implied into the contract of employment to the effect that after its termination the employee will neither disclose to others nor use for his own purposes the information in question. If a term to this effect cannot be implied then, in my opinion, the employee must be regarded as free to use the information in question. And the criteria to be applied in answering the question must be the well tried "officious bystander" or "giving efficacy to the contract" criteria. It is, in my opinion, wrong in principle in cases between ex-employers and ex-

17. See, e.g., Liverpool City Council v. Irwin [1977] A.C. 239.

18. See Hivac v. Park Royal Scientific Instruments Limited [1946] Ch. 169. 
employees to attempt to define the extent of the obligations resting on the ex-employee in respect of confidential information by reference to the "broad principle of equity that he who receives information in confidence shall not take unfair advantage of it". ${ }^{19}$ It is equally wrong in principle, in my opinion, to attempt to define the ex-employee's obligation in respect of confidential information by reference to alleged breaches during the employment of the employee's implied duty of fidelity. It is a generally recognised breach of the implied duty of fidelity for an employee during his employment to make or to memorise a list of his employer's customers in order, after the termination of the employment, to solicit their custom for his competing business. ${ }^{20}$ But it is not a breach of duty for an ex-employee, after the termination of his employment, to solicit for his competing business the custom of those of his ex-employer's customers as have, without any breach of his duty of fidelity, become stored in his memory. ${ }^{21}$ Nor, in my opinion, is an ex-employee in breach of duty if, as soon as his employment has terminated and his duty of fidelity has come to an end, he sits down and makes a list, with a public trade directory as an aide memoire, of as many customers of his ex-employer as he can remember.

In practice, the situations I have described rarely appear clear cut. This is particularly so on interlocutory applications by ex-employers for injunctions to restrain ex-employees from carrying on competing businesses. These are familiar applications to all Chancery judges. There is a commonly found pattern. The employer, often a high tech. company, is faced with a number of its employees giving notice at about the same time. Some will be technicians, some salesmen and, probably, there will be one or two executives among them. After leaving their employment these ex-employees join together and set up a competing business. They approach the ex-employer's customers; they manufacture and offer for sale competing products or services; the prices they quote are pitched just under the ex-employer's prices; the trade literature they produce bears a resemblance to the ex-employer's trade literature; the appliances they manufacture and sell bear a resemblance, visual and functional, to the ex-employer's appliances and, accordingly, appear to incorporate some of the results of the ex-employer's costly research and development. The employer arrives, ex parte, before a Chancery Judge asking for injunctions to restrain the misuse of confidential information, and, in effect, to restrain the continuance of the competing business. The plaintiff's affidavits will usually allege that the ex-employees, in breach of their duty of fidelity, have copied customer lists and price lists while still employed. It will be alleged that the competing appliances incorporate design and technical features derived from the ex-employer's appliances and knowledge of which represents confidential information. It will be alleged that use of this information for the purpose of the competing business represents unfair dealing with

19. Per Lord Denning MR in Seager v. Copydex [1967] I W.L.R. 923.

20. See Wessex Dairies v. Smith [1935] 2 K.B. 80.

21. See Faccenda Chicken v. Fowler [1987] Ch. 117. 
confidential information and should be restrained by injunction.

It is my experience over the past fifteen years or so, as advocate and then as judge, that ex parte relief in these cases has been only rarely justified but regrettably commonly granted. The trend has, I think, now been halted mainly by the Court of Appeal judgment in Faccenda Chicken v. Fowler. ${ }^{22}$ In the Faccenda Chicken case Neill L J, who gave the judgment of the court, concentrated attention on the extent to which, by means of an implied contractual term, an obligation could be imposed on an ex-employee not to divulge or use confidential information. The extent, he held, was very limited. Trade secrets of the secret formula variety, e.g. the Coca-Cola formula, could be protected by an implied contractual term; but, these apart, an employee's knowledge of manufacturing processes, of results of research, of availability of new materials or of spare parts, of the identity of important customers, of prices and profit margins, whether or not acquired in the course of the employment, were part of his general knowledge that he was entitled to exploit for his own purposes after the termination of his employment.

This rigorous limitation of the extent to which competition by ex-employees can be stifled by the playing of the confidential information card was, in my respectful opinion, entirely in accordance with principle and was not at all overdue.

Solicitation of customers by an ex-employee can, if part of the employer's trade goodwill adheres to the employee, be restrained by a suitable express term in the contract. The restraint would almost certainly have to be limited in duration. So, also, competition by ex-employees to whom part of the employer's goodwill adheres, can be restrained by a suitable express term. A geographical as well as a temporal limitation would usually be necessary if the term were to avoid restraint of trade invalidity. A prospective employee faced with employment on terms that incorporate a post-employment restraint of trade clause can decide whether or not he is prepared to accept employment on those terms. If he does not like the proposed restraint he need not accept the employment. If he accepts the employment he does so with his eyes open. If, on the other hand, the terms of employment contain no express restraint on post-employment business competition, the ex-employee should, as a general principle, be regarded as free to compete and to use for the purposes of the competing business all and any skills, knowledge or information acquired in the course of his employment. Only in a very special case, e.g. the secret formula type of case, should an implied term be imposed on him. The implied term will, after all, invariably constitute a restraint of trade. It will be unlimited in time and will be very unlikely to incorporate any geographical limits. If the implied restraint had been embodied in an express term, it would have been a candidate for invalidity on restraint of trade grounds. I would think it almost too obvious to be stated that the Court ought never to impose on an ex-employee an implied restraint that would have been void for illegality if 
contained in an express term of the contract of employment. But a number of cases may be found where, for the protection of so-called confidential information, injunctions have been granted that went further than an express restraint could ever have gone. Perpetual injunctions have in many cases been granted. ${ }^{23}$

May I return to my hypothetical case. The grant of the injunctions sought could not now, post Faccenda Chicken, be justified on breach of duty of confidence grounds except to the extent that the information alleged to be being used was of the trade secret/secret formula variety. Could the injunctions be justified on the ground of breaches of the duty of fidelity committed during the course of the employment? In my opinion, the courts should be very wary of granting injunctions restraining the use of allegedly confidential information on this ground, and should virtually never do so ex parte. There are three reasons for this. First, allegations that customer lists or price lists have been taken or copied are very easy to make and, until trial, very difficult to disprove. Second, the severity of the injunction is usually disproportionate to the gravity of the alleged breach of the duty of fidelity. Let it be accepted that a customer list should not be copied or taken away, nonetheless a short period of work with a trade directory coupled with a legitimate use of memory would in most cases produce much the same result. So the damage caused by the breach would be likely to be trivial. Third, the extent of the implied duty of fidelity must be kept within reasonable bounds. It is not a breach of the duty of fidelity for an employee, even a senior employee or a senior executive, to decide to leave his employment in order to set up in competition. Nor is it a breach if the employee forms the decision some months in advance of giving his notice. Is it a breach if, during his employment, he incorporates and organises the company which is to be the vehicle by means of which he will compete after his employment has come to an end? In my opinion, it is not. Is it a breach if, during his employment, he pays particular attention to some particular research, or to some particular manufacturing process, in order to improve his technical knowledge and to enhance his ability to compete successfully after the termination of the employment? I do not think it is.

The bias of English law is to encourage business competition and to encourage the mobility of labour. The protection given by the law to confidential information must, in my opinion, reflect that bias. It should not be applied so as to tie employees into a modern species of serfdom by making it impossible for them to exploit their acquired skills and knowledge otherwise than for their existing employers. It should not impose on them implied restraints in order to protect employers against competition. If the protection of an employer's confidential information is restricted to the protection that can be justified by implied contractual terms, or, of course, by valid express terms, then, in my opinion, the development of this branch of the law of confidentiality will be in accordance with principle and will reflect social needs and conditions. If, as I think has from time to

23. See, e.g., the injunctions granted in the Cranleigh Engineering case [1964] 3 All E.R, at p.303. 
time happened in the past, the necessity for a contractual justification for protection is lost sight of, the result will be serious injustice to the unfortunate ex-employees and an unjustified restriction on their ability to leave their employment and enter into competition.

\section{The right of privacy}

I have been discussing the law of confidentiality in a contractual context. My thesis is that the rights and obligations of the parties will be both created and limited by the circumstances and exigencies of the particular contract. Rights and obligations in respect of confidential information may also arise in a trust context. ${ }^{24}$ Here, too, the extent of the duty will depend on the particular circumstances of each case. There is no doubt, however, that obligations of confidence can regularly arise in circumstances that have nothing whatever to do with contract or with trust. The question whether these non-contractual and non-fiduciary obligations have their origin in common law or in equity is, to my mind, a sterile one. Breach of them represents an actionable civil wrong arising otherwise than out of contract and otherwise than out of trust. I can see no objection in principle, whatever be the equitable or common law origin of these obligations, to classifying a breach of them as a tort. In a contractual case the breach will also be a breach of contract. ${ }^{25}$ In a trust case, the breach will also be a breach of trust. ${ }^{26}$ These narrower classifications are not inconsistent with the general classification of breaches of obligations of confidence as tort.

The relevance of this classification is that recognition of the nature of noncontractual and non-fiduciary breach of confidence as tort leaves the exploration of the boundaries of the tort to be undertaken pragmatically case by case in much the same way as the boundaries of, say, the tort of negligence and the tort of nuisance are explored. Within the tort of negligence there is recognition of the general principle that due care should be taken to avoid causing physical harm to others. It was at one time supposed that the tort did not extend to harm caused by a defective product to the consumer. This proposition was refuted by Lord Atkin's famous judgment in Donoghue v. Stevenson. ${ }^{27}$ It was at one time supposed that the tort did not extend to harm caused by negligent mis-statements. This was refuted by Denning $\mathrm{LJ}$ in Candler v. Crane, Christmas ${ }^{28}$ and, later and authoritatively, by the House of Lords in Hedley Byrne v. Heller. ${ }^{29}$ Dicta of Lord Wilberforce in Anns v. Merton London Borough Council ${ }^{30}$ have been treated as authority for the principle that due care should be taken to avoid causing economic loss to others. funior

24. See, e.g., Phipps v. Boardman [1967] 2 A.C. 46.

25. Cf. Midland Bank Lid. v. Hett Stubbs v. Kemp [1979] Ch. 384.

26. See Phipps v. Boardman, supra n 24.

27. [1932] A.C. 562.

28. [1951] 2 K.B. 164.

29. [1964] A.C. 465.

30. [1978] A.C. 728. 
Books Ltd. v. Veitchi Co. $L t d .{ }^{31}$ may be regarded as an application of this principle. Later cases have significantly narrowed its scope. ${ }^{32}$ I mention these cases in order to draw attention to the familiar way in which the boundaries of the tort of negligence have been extended or contracted by judicial policy decisions intended to reflect the broad social needs of the times. It is plain enough that this process involves an element of judicial law making. But I think it almost self-evident that judicial law making of this character is, or at least should be, more flexible and more responsive to the changing needs of society than the heavy hand of legislation.

I return to the law of confidence. There are a number of judicial decisions which, by providing a remedy for the misuse of private confidential information have, in effect, given a measure of protection to privacy. It is possible to regard Prince Albert v. Strange as the first case in this line. Argyll v. Argyll is a clearer example. The Duke was subjected to an injunction restraining the disclosure in a national newspaper of intimate marital secrets. The injunction was obtained by his wife, the Duchess. The injunction was not expressed to restrain the Duke from including those secrets in his personal memoirs. It restrained publication of the secrets. The injunction was, therefore, quia timet. The tort, if that is what it is, of misuse of confidential information would have been committed by disclosure of the secrets to others. This decision by Ungoed-Thomas $J$ represented a recognition of the right of the Duchess to have her private life kept private. The decision has been commented on in a number of subsequent cases but its correctness has never, so far as I know, been questioned.

In Stephens v. Avery the plaintiff and the first defendant had been friends. In the course of the friendship the first defendant had become aware of a lesbian relationship between the plaintiff and another woman. The first defendant supplied details of this to the newspaper defendant. The newspaper published the story. The plaintiff claimed damages for breach of confidence. The defendants applied to have the action struck out. The Vice-Chancellor, Sir Nicolas BrowneWilkinson, declined to strike the action out. He held, in line with $A r g y l l$ v. Argyll, that private information relating to sexual conduct was capable of being protected by the law of confidence. ${ }^{34}$

In both Argyll v. Argyll and Stephens v. Avery confidential information had been disclosed by the plaintiff to the defendant. But in Argyll v. Argyll it is likely that some of the relevant information had come to the attention of the Duke not by disclosure on the part of the Duchess, but by observation or participation or simply in the course of domestic cohabitation. There was no distinction drawn

32. See, e.g., D F Estates Ltd. v. Church Commissioners [1989] A.C. 177, Leigh \& Sillavan Ltd. v. Aliakmon Shipping Co. Ltd. [1986] A.C. 785 and Caparo Industries P.L.C. v. Dickman [1990] 2 W.L.R. 358.

33. [1988] Ch. 449.

34. See also Lennon v. Nezws Group Nezwspapers Ltd. [1979] F.S.R. 573. 
between disclosed information and information of the latter character. So it is not a necessary condition of protection that the information should have been specifically disclosed by a confider. This same point was, in another context, emphasised by Lord Griffiths in the Spycatcher case. ${ }^{35}$ Would the result in Argyll v. Argyll have been any different if the Duke had kept private memoirs which had been stolen and if the intending publisher had been the thief? It is, in my opinion, inconceivable that in such a case an injunction against publication would not have been granted to the Duchess. It would not have been granted on breach of copyright grounds for she would not have been the author. It would, I think, have been granted in order to restrain the misuse of confidential information. I have used the adjective "inconceivable" deliberately and, I hope, justifiably. What system of jurisprudence would regard as tortious the publication of the material by the confidant but would permit the publication of the material by the thief? The same point can be made regarding Stephens v. Avery. If the disclosure of the lesbian affairs had been made by letter and if the letter had been stolen and then published by the thief, would the plaintiff's claim in damages against the thief have been struck out? Why should the thief be in a better position than the recipient of the letter?

Authority in support of the view I have been expressing is to be found in Francome v. Mirror Group Newspapers Ltd.. ${ }^{36}$ Unidentified persons tapped telephone conversations to and from the home of the plaintiff, the then champion National Hunt jockey. The Mirror acquired the tapes and the plaintiff sued to restrain their publication. The conversations eavesdropped upon were obviously private conversations. So the injunction was sought on the ground that the Mirror was under a duty to preserve the confidentiality of the conversations. The Mirror's main defence was the "disclosure of iniquity" defence. The Court of Appeal declined, pending trial of the action, to allow the contents of the tapes to be disclosed to the public at large. The importance of the case for present purposes was the recognition that the plaintiff was entitled, prima facie, to have the privacy of his private telephone conversations protected. The contrary view expressed by Sir Robert Megarry, Vice-Chancellor, in Malone v. The Metropolitan Police Commissioner ${ }^{37}$ should, in my opinion, no longer be regarded as good law.

The point has been made that protection against telephone tapping, or for that matter, the use of telephoto lens photography, confuses the duty not to misuse confidential information, which the law recognises, with the right to privacy, which the law does not recognise. It is, I agree, important in these so-called 'privacy' cases to be clear about the rights being protected and to distinguish between the boundaries of the tort of nuisance and the boundaries of the tort of misuse of confidential information. The injunction granted against the Mirror in the Francome case was designed to prevent the misuse of the confidential 
information. But disclosure of the information to the Police or to the Jockey Club was not restrained. It would not have represented misuse. ${ }^{38}$ An injunction was not, however, granted to restrain telephone tapping. In the Malone case the relief sought was a declaration that the tapping of the plaintiff's telephone by the Police had been unlawful, and an injunction to restrain future tapping. The plaintiff did not seek an injunction to restrain the use by the Police of the information they had obtained from the past tapping.

Restraints against telephone tapping must, in my opinion, be justified by reference to the tort of nuisance. This tort protects against behaviour which unreasonably interferes with the occupation and enjoyment of property. Nuisance by smell and nuisance by noise are common examples. Nuisance, like the tort of negligence, has the merit of great flexibility. It enables - and requires - a balance to be struck between the reasonable requirements of members of the public for the peaceful and uninterrupted enjoyment of their homes and the reasonable requirements of others whose activities impinge upon that enjoyment. I can see no reason whatever why, in principle, telephone tapping might not represent actionable nuisance; most people would regard the tapping of their home telephones as an unreasonable interference with their enjoyment of their homes. But whether, in a particular case, the tapping would represent actionable nuisance would depend upon the purpose of the tapping. Tapping by the Police for the prevention of serious crime might suffice as a defence.

On the other hand, injunctions to restrain the disclosure or misuse of private conversations must be justified by reference to the law of confidence. As with nuisance, the law should be recognised as being flexible. The purpose of the proposed use may be critical. In the Francome case, it was publication to the public at large that was restrained.

The confusion to which I have earlier referred would, I think, be avoided if it were recognised that the so-called 'right to privacy' is not, under English law, a free standing enforceable right but is the result of the protection given by a variety of different torts. The tort of trespass provides protection against physical invasions of private property; the tort of nuisance provides protection against unacceptable interference with the enjoyment of private property; the tort of misuse of confidential information - as I would call it - provides, or ought to provide, protection against the misuse of private information. The three together provide rights that can compendiously but inaccurately be described as rights of privacy. Enforcement must, however, identify the apposite tort and bring the complaint within the acceptable boundaries of that tort.

It is, I suggest, now established that private conversations, whether recorded by a party to the conversations, or misappropriated by the theft of some written record, or obtained by the tapping of a telephone, will be protected against misuse. So, too, would intimate family or personal details known to a member of the family 
or of the family circle be protected against misuse. The cases to which I have referred establish that that is so. There is, in my opinion, no sensible reason in principle or in practice for distinguishing between the eavesdropper who overhears private conversations, the "Peeping Tom" who spies through the bedroom curtains, or the intrusive photographer with his long-range telephoto lens. Each of these is, in one way or another, coming into possession of private information. Whether the culprits can be restrained from continuing their disagreeable practices does, I think, depend on the scope of the tort of nuisance. But whether they can be restrained from publication or other commercial exploitation of the information depends, or should depend, on the law of confidence.

It is at this point that I must mention a case, Kaye v. Robertson, reported in The Times on 21 March 1990. As yet a full report is not available. But the facts provide an apt test for the application of the principles and approach for which $I$ have been arguing. The plaintiff was a well known actor, Mr Gordon Kaye, suing by his next friend. Mr Kaye had been involved in a car accident caused by severe gales. He had suffered serious injuries to head and brain. He was taken to hospital and placed under intensive care. A journalist obtained unauthorised access to $\mathrm{Mr}$ Kaye's hospital bed. There the journalist took photographs of $\mathrm{Mr} \cdot \mathrm{Kaye}$, including photographs of the scars on his head. The journalist had no effective consent by Mr Kaye to take these photographs. He was in no better position than if the photographs had been surreptitiously taken with a zoom lens from across the street. The judge at first instance, Potter J, granted an injunction to restrain the publication of the photographs.

The Court of Appeal discharged the injunction and did so, expressing regret, on the ground that English law did not provide a remedy for invasion of privacy. In my respectful opinion, this decision paid insufficient attention to the developing law of confidence. It does not appear from the abbreviated report in The Times that any submission was made as to the application of the law relating to the misuse of confidential information. But, in my opinion, the application of established principles of the law of confidence should have led to the dismissal of the appeal. It must be accepted that if a family friend or relation had, with Mr Kaye's consent, taken the photographs for the purpose of a family album, the friend would have been restrained from publishing the photographs in the national press and a newspaper which had purchased the photographs from the friend or relation would be unlikely to be in any stronger position. Argyll v. Argyll would, in my opinion, be a clear authority to that effect. If the photographs of Mr Kaye's head had, with Mr Kaye's consent, been taken by a doctor for the purpose of use in a teaching hospital or for an illustration in a learned journal, the doctor would have been restrained from general publication and a newspaper purchaser from the doctor would be unlikely to be in any stronger position. If a doctor had taken the photographs without Mr Kaye's consent he might have been able to justify publication in a medical journal or for teaching purposes provided he avoided 
identifying $\mathrm{Mr}$ Kaye as the subject, but would not have a hope of justifying publication in a national newspaper which revealed the identity of $\mathrm{Mr}$ Kaye as the subject of the photograph.

How did it come about that the Court of Appeal treated the unauthorised photographs taken by a trespasser as giving more extensive rights to the photographer than would have been the case had permission been sought? In my opinion, expressed with diffidence pending the availability of a full report, the Court of Appeal concentrated on the absence of a so-called right to privacy rather than on the content of the photographs and the circumstances in which they were taken. The photographer should, in my opinion, have been held to be no more entitled to publish his photographs than the Daily Mirror was entitled to publish the transcripts of the tapped telephone conversations in the Francome case. The Court of Appeal decision in Kaye v. Robertson is, in my view, inconsistent with the earlier decision in Francome. There is, however, no indication from the report in The Times that Francome v. Daily Mirror was cited or, indeed, that the breach of confidence line of cases was mentioned at all.

In The Times Report of Kaye v. Robertson, Bingham $\mathrm{LJ}$ is reported as saying that "the case highlighted the failure of . . the common law of England . . . to protect in an effective way the personal privacy of individual citizens." Leggatt LJ is reported as saying that a right to privacy "had been so long disregarded here that it could be recognised now only by the legislature ..."

These gloomy prognostications may turn out to be right. But, it seems to me, judicial willingness to explore the boundaries of the protection that can be given to confidential information can cover much of the area that the dicta in Kaye v. Robertson treat as unprotected by the law. It is, I repeat, now well established that for information or material to be protected on the ground of confidentiality it is not essential that there should be a 'discloser'; it is not essential that the information or material should have been received from the person claiming to be entitled to the protection; it is, I think, established to be sufficient if the information or material is obviously of a private nature and if it is obvious that consent by the person who is the subject of the information or material to its publication would not be given. If this requirement is satisfied, the availability of protection against publication should depend upon the familiar balance being struck between the public or private interests to be served by keeping the material private and confidential and the public or private interests to be served by publication. As long ago as 1913 Swinfen Eady J said in Ashburton v. Pape $e^{39}$ that "the principle upon which the Court of Chancery has acted for many years has been to restrain the publication of confidential information improperly or surreptitiously obtained..." It is but a tiny step to regard photographs taken surreptitiously as potentially within the scope of this dictum. I can see no reason why, some 77 years on, with the judicial development of concepts of confidentiality that has taken place in the meantime, 
the common law (including, for this purpose, equity) should not provide the right to privacy that the facts of Kaye v. Robertson seem to demand. Provided the flexibility of the developing tort of misuse of confidential information is accepted and used, I do not believe there is a need for legislation.

\section{Conclusion}

I have in this Article dealt with two very disparate aspects of the law of confidence. But I think they provide an interesting contrast. In the employer/employee cases, misuse of confidential information concepts have in the past been over used for the purpose of placing unjustifiable restraints on the ability of ex-employees to carry on competing businesses. However, the law has now been stabilised by the Court of Appeal decision in Faccenda Chicken v. Fowler. In the privacy cases, on the other hand, an apparently fruitful development of the law by means of the application of misuse of confidential information concepts has appeared to be blighted by the Court of Appeal decision in Kaye v. Robertson. It is to be hoped that the blight is no more than an unseasonal frost and that the sun will soon shine again. I do not see any reason why it should not. 